\title{
Psychic and moral exhaustion in primary care workers*
}

\author{
Desgaste psíquico-moral nos trabalhadores da atenção primária \\ Desgaste psíquico moral en los trabajadores de la atención primaria
}

\author{
Priscilla Brandão Bacci Pegoraro' ${ }^{1}$, Rafaela Schaefer ${ }^{1,2}$, Elma Lourdes Campos Pavone Zoboli ${ }^{3}$
}

How to cite this article:

Pegoraro PBB, Schaefer R, Zoboli ELCP. Psychic and moral exhaustion in primary care workers. Rev Esc Enferm USP. 2017:51:e03257. DOI: http://dx.doi. org/10.1590/S1980-220X2016035203257

\author{
* Extracted from the dissertation: "Desgaste \\ Psíquico Moral na Atenção Primária à Saúde: \\ uma proposta de enfrentamento para a gestão \\ local do Município de Campinas - SP", Escola de \\ Enfermagem, Universidade de São Paulo, 2015. \\ ${ }^{1}$ Universidade de São Paulo, Escola de \\ Enfermagem, Programa e Pós-Graduação \\ em Enfermagem, São Paulo, SP, Brazil. \\ ${ }^{2}$ Universidade Católica Portuguesa, Instituto \\ de Ciências da Saúde, Porto, Portugal. \\ ${ }^{3}$ Universidade de São Paulo, Escola de \\ Enfermagem, Departamento de Enfermagem \\ em Saúde Coletiva, São Paulo, SP, Brazil.
}

\begin{abstract}
Objective: To report the experience of developing a workshop proposal to assist local managers with the identification, management and prevention of primary care workers' psychic and moral exhaustion. Method: The workshop was developed through a literature review performed between November 2014 and June 2015. The temporal cut considered studies of the ten previous years. The selection included studies describing collective interventions for situations generating psychic and moral exhaustion, preferably in primary care services. Results: Thirty-five articles were analyzed. The workshop provides five meetings with an average duration of one hour. The themes are: awareness; recognizing personal stress; dealing with personal stress; recognizing team stress; and dealing with team stress. The workshop is based on five key principles: detection and coping; attention to interpersonal relationships; communication; self-knowledge and mindfulness. Conclusion: Psychic and moral exhaustion may reflect negatively on workers' health, the care, and the organization. The proposal of measures to recognize, deal with and prevent psychic and moral exhaustion is relevant and strategic in the constant search for improvement of satisfaction and quality.
\end{abstract}

\section{DESCRIPTORS}

Health Personnel; Primary Care Nursing; Professional Exhaustion; Worker's Health; Moral Damage; Primary Health Care.
Corresponding author:

Rafaela Schaefer

Rua Dr. António Bernardino de Almeida, 400 4200-072 - Porto, Portugal

rafaelaschaefer1988@gmail.com
Received: 09/15/2016

Approved: 05/05/2017 


\section{INTRODUCTION}

The work environment can be an important means when discussing psychic and moral exhaustion, especially in primary care services, where the gap between professional moral commitment and workplace conditions can generate conflicts related to fundamental aspects of workers' health ${ }^{(1)}$. Investing in the identification and analysis of causes of workers' health conditions is essential to elaborate initiatives with the aim to reduce illness rates and preserve the health of these professionals ${ }^{(2)}$.

In the health area, conditions related to professionals' psychic and moral exhaustion are among the main reasons for illness and absence from work ${ }^{(3-4)}$. Psychological disorders do require attention because they can interfere with biopsychosocial behavior and professional performance, and increase organizations costs ${ }^{(5)}$. The current scenario is worrisome: a recent study conducted with nursing workers from all over Brazil shows that $64 \%$ of professionals consider themselves to be in process of professional exhaustion ${ }^{(6)}$.

Burnout and moral distress (among others) are at the core of conditions leading to the psychological and moral exhaustion of health workers ${ }^{(7)}$. The Burnout syndrome reflects emotional exhaustion, depersonalization, and lack of achievement related to work ${ }^{(8)}$. It is a serious problem of psychosocial character ${ }^{(9)}$ often associated with heavy workload that can lead to symptoms of exhaustion, fatigue and irritation $^{(10)}$. Moral distress, in turn, is the result of restriction to an intended moral action associated with symptoms of dissatisfaction, frustration, and distance from patients ${ }^{(11)}$.

Even though nurses' training prioritizes the excellence of clinical care, these professionals are the main protagonists of management roles in primary care services. Among the main barriers generating work stress, are incomplete teams, lack of training of some professionals for work, lack of financial resources and lack of materials and equipment ${ }^{(12)}$.

There are few studies proposing interventions to solve problems associated with the psychic and moral exhaustion of health workers, especially in primary care services ${ }^{(13)}$. The present study was designed to contribute with filling this gap through the search and development of technologies to improve work processes. Thus, workshops can be the systematization of an intervention because they presuppose an emancipatory and critical nature by using non-habitual or formal elements, and allow the recovery of participants' spontaneity ${ }^{(13)}$.

Considering the fundamental role of managers in reducing the psychic and moral exhaustion of workers, the objective of the study was to report the experience of developing a workshop proposal to help managers identify and manage the psychic and moral exhaustion of primary care workers.

\section{METHOD}

This is an experience report about the theoretical elaboration of a workshop proposal to train managers in the recognition and collective coping with psychic and moral exhaustion of health workers, especially in primary care.
For the preparation of the workshop, between November 2014 and June 2015 was conducted a literature review in the following databases: Virtual Health Library Portal VHL, which integrates the IBECS databases - Spanish Bibliographic Index of Health Sciences, LILACS - Latin American and Caribbean Literature in Health Sciences, SCIELO - Scientific Electronic Library Online and COCHRANE Library. The descriptors used were: Professional Exhaustion; Moral damage; Workers Health; And Primary Health Care. The temporal cut of the survey (for convenience) were the ten previous years. The languages of articles were Portuguese, English or Spanish.

The selection criteria considered texts on interventions for the collective confrontation of situations of psychic and moral exhaustion. It were identified 337 articles related to professional exhaustion, moral damage and workers health, of which 11 were selected. Another 129 articles related to professional exhaustion, moral damage and primary health care were identified, of which 24 were selected. In total, 35 articles were analyzed in full (Figure 1 ).
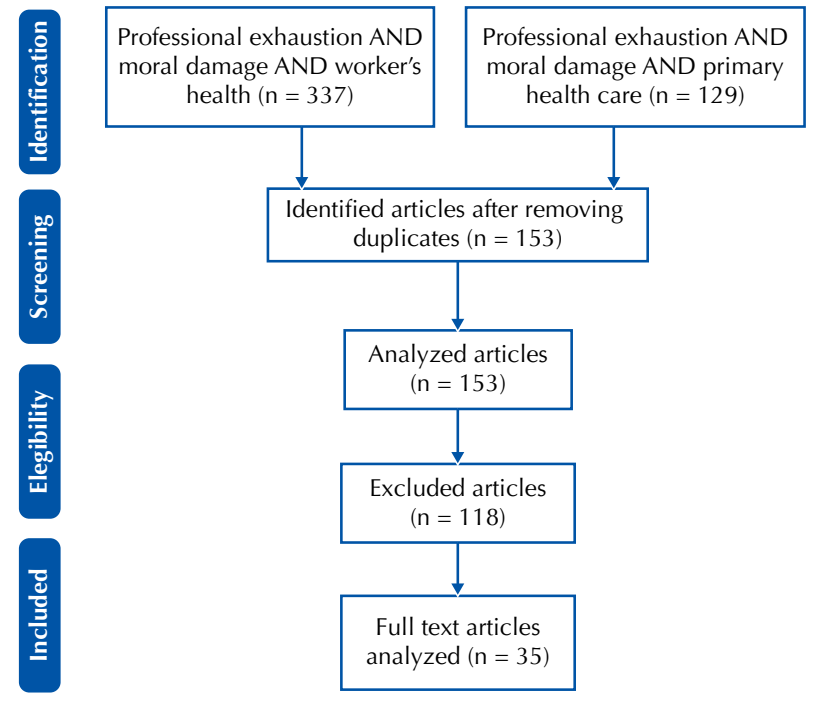

Figure 1 - Flowchart of the search and selection of studies included in the review.

The content included in the workshop proposal was based on the analysis of the literature, and its methodological development was based on specific bibliography ${ }^{(14-16)}$. It included weekly meetings of average duration of one hour, and participation of between six and 15 people. The meetings are structured and include activities beyond the usual forms of communication, that is, oral and written. The suggestion is to start with a brief warm up, followed by a reflection on the issue through the manipulation of materials such as magazines, pictures, modeling clay, waste materials, colored threads, ink, paper. The communication between participants is mediated by the production of concrete material, which allows for greater detail and a deeper discussion.

The report of participants' concrete production triggers the discussion that is aimed at the sharing and problematization of the theme. The purpose is helping people overcome common sense by articulating the singular, particular and 
structural dimensions involved in the realities pertinent to the theme. This leads to wider possibilities of interpretation of problems and confrontations ${ }^{(14)}$.

Since the study does not involve research subjects, it was not necessary to request approval by the Research Ethics Committee.

\section{RESULTS}

The review of the literature allowed the identification of theoretical references, health policies, strategies and practices for coping with the psychic and moral exhaustion and health promotion of workers, which supported the proposal of creating the workshop intended for managers of Basic Health Units. The purpose of the workshop is helping managers with the development of skills and competencies to recognize situations that generate psychic and moral exhaustion, and strategies to deal with and prevent the team distress.

From the analysis of studies, the main factors identified as responsible for the psychic and moral exhaustion were moral distress $^{(7,13,17-19)}$ and burnout syndrome $e^{(2,5,7,20-22)}$. The analyzed studies were performed mainly with nurses, and describe moral distress and Burnout as frequent phenomena in the reality of different health work contexts.
Regarding coping strategies, the studies highlight the importance of a collective approach based on organizational intervention strategies ${ }^{(22)}$. The key to the success of this type of intervention is ensuring a multivariate and prolonged nature, and considering the relationships between organization, structure and individual ${ }^{(13)}$.

The process of workshop development took into account the literature findings to propose the following as key principles for reducing psychic and moral exhaustion: detection and coping $^{(5,22-23)}$, attention to interpersonal relationships ${ }^{(24-26)}$, communication $^{(27)}$, self-knowledge and mindfulness ${ }^{(28)}$.

Mindfulness is a group intervention that allows selfregulation and has the objective to bring the mind or mental state into the present. There are several techniques to stimulate and develop mindfulness, and the most known are those derived from meditation. The central objective is to promote well-being and quality of life. The specific objectives are diverse, according to the nature of the actions and environments where programs are developed ${ }^{(29)}$.

The workshop is planned for five meetings that should take place in the hour before managers' weekly meetings to avoid interference with the work organization and additional displacement of people. Meetings are described in Chart 1.

Chart 1 - Description of the five meetings proposed for the workshop on identification and management of psychic and moral exhaustion of primary care workers - São Paulo, SP, Brazil, 2015.

\begin{tabular}{|c|c|c|}
\hline Meetings & Components & Description \\
\hline \multirow{7}{*}{$1^{\text {st }}$ meeting Awareness } & Objective & $\begin{array}{l}\text { To raise awareness about the issue of psychic and moral exhaustion among health } \\
\text { professionals. }\end{array}$ \\
\hline & Key concepts & $\begin{array}{l}\text { Psychic and moral exhaustion - Burnout and Moral Distress. Factors that trigger psychic and } \\
\text { moral exhaustion and the impacts on the care, the health of individuals, and the institution. }\end{array}$ \\
\hline & Materials & $\begin{array}{l}\text { Magazines to cut, scissors, glue, paper, sequins, fabric strips, marker pen, data show, notebook, } \\
\text { loose chairs. There should be enough physical space to accommodate all participants in a } \\
\text { circle and a support desk to do the activities and organize the materials. Meetings should be } \\
\text { recorded by some means. }\end{array}$ \\
\hline & $\begin{array}{l}\text { Warm up } \\
\text { (30 minutes) }\end{array}$ & $\begin{array}{l}\text { Each participant receives an A4 sheet and magazines to make cut outs and collage of words } \\
\text { and pictures that represent their stress at work. Participants are advised to represent their } \\
\text { understanding, the factors and levels of stress as they wish, that is, there is no guidance from } \\
\text { the instructor in this aspect. Those who feel comfortable will be asked to make comments on } \\
\text { the panel they have set up, thus starting the problematization of stress at work. }\end{array}$ \\
\hline & $\begin{array}{l}\text { Workshop } \\
\text { (20 minutes) }\end{array}$ & $\begin{array}{l}\text { After the warm up and problematization, is prepared the synthesis presentation on Burnout } \\
\text { and Moral Distress. With use of media, are prepared Power Point slides that show the } \\
\text { synthesis of key concepts. }\end{array}$ \\
\hline & Dispersion activity & $\begin{array}{l}\text { 'Stress savings account' - the task is identifying the times when the participant feels stressed, } \\
\text { tired, or exhausted during the week. In these moments, should observed which activities or } \\
\text { issues have awakened each of the feelings or states of mind, trying to identify the situations } \\
\text { representing greater tendency to stress. Participants will also be asked to be aware of how } \\
\text { they coped with stressful situations. A small safe box, and red, yellow and green colored } \\
\text { coins will be used to perform this activity. Each color represents a stressful situation: Red - } \\
\text { highly stressful situations. Yellow - moderately stressful situations. Green - calm, non-stressful } \\
\text { situations; on the contrary, they are pleasurable and not stressful like the previous ones. For } \\
\text { each situation observed in day to day work, the participant will deposit a coin related to the } \\
\text { situation in the safe box. If the manager wants or feels the need, he/she can make a journal } \\
\text { describing the situation related to each coin, indicating the color of the coin, date, time and } \\
\text { location of the situation, how he/she coped with stress and feelings experienced at the time. }\end{array}$ \\
\hline & Check out & $\begin{array}{l}\text { Participants are invited to make comments on the meeting and how they felt by using an } \\
\text { intermediary object, for example, a plush object is passed to each person at the moment they } \\
\text { are invited to speak. Manifestation is spontaneous. }\end{array}$ \\
\hline \multirow{3}{*}{$\begin{array}{l}2^{\text {nd }} \text { meeting } \\
\text { Recognizing personal } \\
\text { stress }\end{array}$} & Objective & $\begin{array}{l}\text { To problematize the dispersion activity and present a new possibility of coping with stress: } \\
\text { mindfulness. }\end{array}$ \\
\hline & Key concepts & Mindfulness. \\
\hline & Materials & $\begin{array}{l}\text { There should be enough physical space to accommodate all participants in a circle, and } \\
\text { a support desk to perform the activities and organize the materials. Meetings should be } \\
\text { recorded by some means. Loose chairs. Notebook, data show and speakers. }\end{array}$ \\
\hline
\end{tabular}

continued.. 
...continuation

\begin{tabular}{|c|c|c|}
\hline Meetings & Components & Description \\
\hline \multirow{4}{*}{$\begin{array}{l}2^{\text {nd }} \text { meeting } \\
\text { Recognizing personal } \\
\text { stress }\end{array}$} & $\begin{array}{l}\text { Warm up } \\
\text { (20 minutes) }\end{array}$ & $\begin{array}{l}\text { Participants are invited to open their safe boxes and observe comparatively the quantities of } \\
\text { coins of each color. They can count the quantity of each one if they wish. Each participant } \\
\text { should present the feeling of performing the activity. How did I feel putting the coin in the safe } \\
\text { box? How do I perceive stressful situations? What are they related to? If a participant wants to } \\
\text { share with the group some situation experienced during the week, this is the moment. Starting } \\
\text { the problematization of how we recognize and cope with our stress. }\end{array}$ \\
\hline & $\begin{array}{l}\text { Workshop } \\
\text { (30 minutes) }\end{array}$ & $\begin{array}{l}\text { Presentation of the video 'Mindfulness in the Corporate World'(14). Through the video, } \\
\text { participants will have contact with mindfulness as a technique that has been disseminated in } \\
\text { various working environments, including public health, with a view to improve personal and } \\
\text { professional quality of life, reduction of stress and pathologies. After the video presentation, } \\
\text { the discussion can start with the questions: Has anyone heard of this strategy for coping with } \\
\text { stress? How could it be applied? }\end{array}$ \\
\hline & Dispersion activity & $\begin{array}{l}\text { 'Investing in mindfulness' - using the safe box again, participants are invited to re-observe } \\
\text { their daily life, and elect a routine activity to exercise focus. That is, the participant should } \\
\text { choose a regular activity, for example, taking a shower, to perform it with mindfulness. The } \\
\text { person should keep full attention on the chosen activity at the time of performing it, in order } \\
\text { to transform automatic actions such as bathing, into conscious actions. At the end of the } \\
\text { activity, the participant should put a coin in the safe box according to the focus kept: Red if } \\
\text { the participant was not able to perform the activity with attention. Yellow, if the activity was } \\
\text { performed with medium attention. Green, if the chosen activity could be performed with } \\
\text { attention focused only on it, that is, with full attention on what was done. }\end{array}$ \\
\hline & Check out & $\begin{array}{l}\text { Participants are invited to make comments on the meeting, their feelings, and the benefits } \\
\text { through an intermediary object as a plush object (different from the object used previously), } \\
\text { which is passed on to those who wish to manifest themselves. }\end{array}$ \\
\hline \multirow{7}{*}{$\begin{array}{l}3^{\text {rd }} \text { meeting } \\
\text { Dealing with personal } \\
\text { stress }\end{array}$} & Objective & To perform the practical activity of mindfulness and know ways to cope with stress. \\
\hline & Key concepts & Practice of mindfulness. \\
\hline & Materials & $\begin{array}{l}\text { A container with raisins in enough quantity for the ingestions of three units by each participant. } \\
\text { A support table, and enough physical space and loose chairs to accommodate all participants } \\
\text { in a circle. Notebook, data show and speakers. }\end{array}$ \\
\hline & $\begin{array}{l}\text { Warm up } \\
\text { (20 minutes) }\end{array}$ & $\begin{array}{l}\text { Participants are invited to open their safe boxes and observe comparatively the quantities of } \\
\text { coins of each color. They can count the quantity of each one if they wish. Each participant } \\
\text { will be invited to talk about their experience, the feeling experienced when performing the } \\
\text { routine activity (usually done automatically) with full attention on what was done in each } \\
\text { step. }\end{array}$ \\
\hline & $\begin{array}{l}\text { Workshop } \\
\text { (30 minutes) }\end{array}$ & $\begin{array}{l}\text { Raisins dynamics }{ }^{(15)} \text { - the objective is that each participant can experience the difference } \\
\text { between performing an action in a state of ordinary awareness and performing the same } \\
\text { action with full attention. To this end, each participant will be invited to eat three raisins, } \\
\text { one at a time. } \\
\text { - First raisin: the participant can eat the raisin as usual. Once ingested, there will be a } \\
\text { moment for a brief silent reflection on the experience. } \\
\text { - Second raisin: the participant will be invited to maintain full attention during the whole } \\
\text { process of eating the raisin, following the instruction steps. } \\
\text { - Third raisin: the participant is asked to take the third raisin and eat it with full attention, } \\
\text { but this time, without the instructor's guidance. Each participant must follow their own pace. } \\
\text { At the end, participants are invited to share spontaneously with the group their experiences } \\
\text { at the different times. }\end{array}$ \\
\hline & Dispersion activity & $\begin{array}{l}\text { Participants must find the 'raisin' in their work, in which they will put full attention. It can } \\
\text { be a problem or a task. The important matter is to perform the activity with mindfulness by } \\
\text { observing and noting the most relevant aspects of the experience. }\end{array}$ \\
\hline & Check out & $\begin{array}{l}\text { Participants are invited to make comments on the meeting, on how they are feeling and how } \\
\text { is their attention, through an intermediate object (it can be the same plush object used in the } \\
\text { first meeting) that is passed on to those who wish to manifest themselves. }\end{array}$ \\
\hline \multirow[b]{5}{*}{$\begin{array}{l}4^{\text {th }} \text { meeting } \\
\text { Recognizing team stress }\end{array}$} & Objective & $\begin{array}{l}\text { To recognize and identify the impacts of Burnout and moral distress on team performance, } \\
\text { organizational environment, and quality of care. }\end{array}$ \\
\hline & Key concepts & Forms of psychic and moral exhaustion in teamwork. \\
\hline & Materials & $\begin{array}{l}\text { Loose chairs to accommodate all participants in a circle, cards made with pictures (pictures } \\
\text { should contain only images, avoid writing or marks). Cards should be all the same size, cut in } \\
\text { rectangular shape with pictures glued in the center. Pictures do not need to be the same size. }\end{array}$ \\
\hline & $\begin{array}{l}\text { Warm up } \\
(20 \text { minutes) }\end{array}$ & $\begin{array}{l}\text { Group members who feel comfortable shall make comments on the dispersion activity of } \\
\text { the previous meeting, presenting the situation chosen to focus their attention on, the most } \\
\text { relevant points of the experience and the results achieved. }\end{array}$ \\
\hline & $\begin{array}{l}\text { Workshop } \\
\text { (30 minutes) }\end{array}$ & $\begin{array}{l}\text { Participants are invited to think about how they perceive interpersonal relationships and } \\
\text { routine work, if they recognize exhaustion in the team, and how the team deals with it. The } \\
\text { instructor will make sure this moment does not become an opportunity to blame the team or } \\
\text { make moral or performance judgments. The card dynamics will be used for this activity. The } \\
\text { cards with pictures made previously will be placed at the center of a table, and participants will } \\
\text { be invited to circulate and observe the pictures. After some time of observation, they should } \\
\text { choose an image, or two, that represents the performance of the team they manage. After the } \\
\text { choice, they will be invited to share with the group the reason for choosing that image. The } \\
\text { group will be encouraged by the instructor to reflect on the theme of their team's performance. } \\
\text { After the presentation of all participants, the instructor will summarize the impacts of Burnout } \\
\text { and moral distress on the health team, recognize and identify the main forms of illness in the } \\
\text { team, and may use or problematize the examples brought by participants. }\end{array}$ \\
\hline
\end{tabular}

continued... 
...continuation

\begin{tabular}{|c|c|c|}
\hline Meetings & Components & Description \\
\hline \multirow[t]{2}{*}{$\begin{array}{l}\quad 4^{\text {th }} \text { meeting } \\
\text { Recognizing team stress }\end{array}$} & Dispersion activity & $\begin{array}{l}\text { 'Journal of my team' - this week, participants will be asked to look more closely at their } \\
\text { team, identifying positive behaviors of the team, behaviors or situations that trigger conflicts, } \\
\text { the ways of coping with conflicts, the dynamics of teamwork, the dynamics of the team's } \\
\text { relationship with the local manager, individual characteristics of workers, especially the best } \\
\text { skills and competencies of each one. Participants will be invited to record their observations } \\
\text { in a journal and to bring notes in the next meeting. If the local manager is in a Family Health } \\
\text { Unit, one of the units can be chosen for this activity. }\end{array}$ \\
\hline & Check out & $\begin{array}{l}\text { Participants are invited to make comments on the meeting spontaneously; how they are } \\
\text { feeling, among other things through an intermediary object, which will be a plush heart in } \\
\text { this meeting. It will be passed on to those who want to manifest themselves. }\end{array}$ \\
\hline \multirow{6}{*}{$\begin{array}{l}5^{\text {th }} \text { meeting } \\
\text { Dealing with team stress }\end{array}$} & Objective & $\begin{array}{l}\text { Present the nonviolent communication (NVC) as a way for the team coping with conflict } \\
\text { situations at work. }\end{array}$ \\
\hline & Key concepts & $\begin{array}{l}\text { NVC, pillars of work relations, basic conditions for teamwork, work dynamics and necessary } \\
\text { skills for team management. }\end{array}$ \\
\hline & Materials & $\begin{array}{l}\text { Loose chairs, explanatory support material with key concepts to be worked, picture cards } \\
\text { used in the previous meeting and box for deposit of suggestions. }\end{array}$ \\
\hline & $\begin{array}{l}\text { Warm up } \\
\text { (10 minutes) }\end{array}$ & Participants who feel comfortable can share their notes and observations about the team. \\
\hline & $\begin{array}{l}\text { Workshop } \\
\text { (40 minutes) }\end{array}$ & $\begin{array}{l}\text { Participants will be divided into groups to get in touch with the key concepts presented in } \\
\text { the support material offered. Each group will be responsible for identifying, consolidating } \\
\text { and presenting some of the concepts to the others. The support material will provide insights } \\
\text { on: NVC, pillars of interpersonal relationships at work, strengthening of teamwork, aspects } \\
\text { related to work dynamics and important skills of the manager. After the discussion in the } \\
\text { small group, there will be a plenary session for presentation and synthesis. }\end{array}$ \\
\hline & Closure and evaluation & $\begin{array}{l}\text { Using the picture cards from the previous meeting, participants will be asked to evaluate the } \\
\text { workshop: how did it contribute to their work as a local manager when coping with situations } \\
\text { of stress and exhaustion of the teams? Participants will also be invited to make suggestions } \\
\text { that may be deposited in the box available for this. }\end{array}$ \\
\hline
\end{tabular}

Throughout the workshop, the term 'stress' is used as a strategic concept to increase managers' interest and participation, and concepts of Burnout and moral distress are addressed throughout the meetings. This type of strategy can be applied and replicated in any primary care context and does not require investment on hard technology, only time and space in schedule for learning and developing a soft technology ${ }^{(14)}$.

\section{DISCUSSION}

Difficulties of the health system, such as long queues, lack of beds, scarce resources, the demand and difficulty of access can directly affect professionals involved in care. This can generate dissatisfaction, especially in primary care services, which are users' gateway to the health system $^{(21)}$. In addition, the work environment can be a determining factor for the quality of care and patients' outcomes ${ }^{(30)}$. The critical point in this type of problem is that professionals may experience difficulties as part of work routine, often not realizing what is happening before feeling depleted ${ }^{(2)}$.

The concern with this theme is confirmed in the 20122015 National Health Plan that describes the importance of personnel management for training, allocation, qualification, valorization and democratization of work relations ${ }^{(31)}$. To improve the quality of life at work, the literature suggests the adoption of intervention strategies of institutional nature, such as training, courses and workshops with the aim to minimize damages and prevent situations such as absenteeism and taking work leave ${ }^{(32)}$.

This type of intervention can represent a viable tool in reducing the negative effects of work-related psychic and moral exhaustion, as long as there is support from the institution in the process ${ }^{(33)}$. The application of this type of strategy has an example with positive results, and reports of improved personal well-being, emotional exhaustion, depersonalization and personal fulfillment ${ }^{(34)}$.

Besides personal aspects, the success of this type of strategy can generate impacts in reduction of work-associated costs. Costs of absenteeism and taking work leave for workrelated mental illness far outweigh the costs associated with improving work conditions, such as reducing working hours and hiring the adequate numbers of professionals ${ }^{(35)}$.

In this context, many professionals end up cultivating the desire to quit the job or even abandon the profession ${ }^{(36)}$. Of these, despite their desire to leave, only a small portion effectively leaves their working position and most remain in their jobs for various contextual factors, such as shortage of other jobs ${ }^{(37)}$. This reality requires that researchers, managers and nursing leaders work together to identify and implement strategies to deal with the psychic and moral exhaustion of health workers in order to improve retention and job satisfaction ${ }^{(38)}$.

Nurses in leading positions, such as managers, would be more likely to experience psychic and moral exhaustion mainly because of the inherent complexity in the decisionmaking process that involves expectations of the organization, patients, and workers ${ }^{(39)}$. Studies seeking to collaborate for the success of the managerial role of nurses - who are increasingly protagonists on the path to achieve institutional health and quality objectives - should be encouraged.

This study reports the proposal of a workshop theoretically designed with the intention of collaborating in improving working conditions and increasing the level of professional satisfaction. A limiting factor is the need for practical 
application of the proposal, a fundamental step to enable the evaluation of results and confirm their effectiveness.

\section{CONCLUSION}

The psychic and moral exhaustion phenomenon affects a large number of health professionals hence, it must be approached from prevention and coping measures in the organizational scope. Such initiatives can contribute to reduce absenteeism, work leave, organizational costs, and improve outcomes.

Workshops with the purpose of improving the organizational environment, stimulating teamwork, facilitating coexistence and communication, and teaching about tools for the recognition and management of situations that generate psychic and moral exhaustion have proven very effective, including with primary care service workers. The workshop proposed in this study intends to collaborate with the practice by stimulating the identification, understanding and coping with psychic and moral exhaustion in work routine.

The product resulting from this report is a material with great potential of applicability and reproduction for managers of primary care services, aiming at a return to society. It is necessary to continue this study with the development of research that follows the possibilities and evaluate the effects of using the workshop, considering the local health management routine.

\section{RESUMO}

Objetivo: Relatar a experiência de elaboração de uma proposta de oficina para auxiliar gestores locais a identificar, manejar e prevenir o desgaste psíquico-moral de trabalhadores da atenção primária. Método: A oficina foi elaborada através de revisão da literatura, entre novembro de 2014 e junho de 2015. O recorte temporal considerou trabalhos dos últimos dez anos. Foram selecionados estudos que descreviam intervenções coletivas para situações geradoras de desgaste psíquico-moral, preferencialmente na atenção primária. Resultados: Foram analisados 35 artigos. A oficina prevê cinco encontros, com duração média de 1 hora. Os temas são: sensibilizar-se; reconhecer o estresse pessoal; lidar com o estresse pessoal; reconhecer o estresse da equipe; e lidar com o estresse da equipe. A oficina é fundamentada em cinco princípios-chave: detecção e enfrentamento; atenção às relações interpessoais; comunicação; autoconhecimento e mindfulness. Conclusão: $\mathrm{O}$ desgaste psíquico-moral pode refletir negativamente na saúde do trabalhador, no cuidado e na organização. A proposta de medidas para reconhecer, lidar e prevenir o desgaste psíquico-moral é considerada pertinente e estratégica, na busca constante pela melhoria da satisfação e da qualidade.

\section{DESCRITORES}

Pessoal de Saúde; Enfermagem de Atenção Primária; Esgotamento Profissional; Saúde do Trabalhador; Dano Moral; Atenção Primária à Saúde.

\section{RESUMEN}

Objetivo: Relatar la experiencia de elaboración de una propuesta de taller para auxiliar a gestores locales a identificar, manejar y prevenir el desgaste psíquico moral de trabajadores de la atención primaria. Método: El taller fue elaborado mediante revisión de la literatura, entre noviembre de 2014 y junio de 2015 . El recorte temporal consideró trabajos de los últimos diez años. Fueron seleccionados estudios que describían intervenciones colectivas para situaciones generadoras de desgaste psíquico moral, preferentemente en la atención primaria. Resultados: Fueron analizados 35 artículos. El taller prevé cinco encuentros, con duración media de 1 hora. Los temas son: sensibilizarse; reconocer el estrés personal; manejar el estrés personal; reconocer el estrés del equipo; y manejar el estrés del equipo. El taller está fundado en cinco principios clave: detección y enfrentamiento; atención a las relaciones interpersonales; comunicación; autoconocimiento y mindfulness. Conclusión: El desgaste psíquico moral puede reflejarse negativamente en la salud del trabajador, el cuidado y la organización. La propuesta de medidas para reconocer, manejar y prevenir el desgaste psíquico moral se considera pertinente y estratégica, en la búsqueda constante por la mejoría de la satisfacción y la calidad.

\section{DESCRIPTORES}

Personal de Salud; Enfermería de Atención Primaria; Agotamiento Profesional; Salud Laboral; Daño Moral; Atención Primaria deSalud.

\section{REFERENCES}

1. Trindade LL, Pires DEP. Implications of primary health care models in workloads of health professionals. Texto Contexto Enferm. 2013;22(1):36-42.

2. Trindade LL, Lauter L. Syndrome of Burnout among the workers of the Strategy of Health of the Family. Rev Esc Enferm USP. 2010;44(2):274-9.

3. Dilélio AS, Fachini LA, Tomasi E, Silva SM, Thumé E, Piccini RX, et al. Prevalência de transtornos psiquiátricos menores em trabalhadores da atenção primária à saúde das regiões Sul e Nordeste do Brasil. Cad Saúde Pública. 2012;28(3):503-14.

4. Prochnow A, Magnago TSBS, Urbanetto JS, Beck CLC, Lima SBS, Greco PBT. Work ability in nursing: relationship with psychological demands and control over the work. Rev Latino Am Enfermagem. 2013;21(6):1298-305.

5. Ferrari R, França FM, Magalhães J. Avaliação da Síndrome de Burnout em profissionais da saúde: uma revisão integrativa da literatura. Rev Eletr Gestão Saúde. 2012;3(3):1150-65.

6. Conselho Federal de Enfermagem. Pesquisa inédita traça perfil da Enfermagem. [Internet]. Brasília: COFEN; 2015 [citado 2016 jul. 18]. Disponível em: http://www.cofen.gov.br/pesquisa-inedita-traca-perfil-da-enfermagem_31258.html

7. Dalmolin GL, Lunardi VL, Lunardi GL, Barlem ELD, Silbeira RS. Moral distress and Burnout syndrome: are there relationships between these phenomena in nursing workers? Rev Latino Am Enfermagem. 2014;22(1):35-42.

8. Organização Mundial da Saúde. CID-10: Classificação Internacional de Doenças. 10a ed. São Paulo: EDUSP; 1997. 
9. Ferrari R, Araujo A, Rodrigues HA, França FM, Magalhães J. Estresse crônico ocupacional em profissionais da estratégia de saúde da família. Em Extensão (Uberlândia). 2013;12(2):83-92.

10. Trindade LL, Lauter L, Beck LC. Coping mechanisms used by non-burned out and burned out workers in the family health strategy. Rev Latino Am Enfermagem. 2009;17(5):607-12.

11. Harrowing JN, Mill J. Moral distress among Ugandan nurses providing HIV care: a critical ethnography. Int J Nus Stud. 2010;47(6):723-31.

12. Fernandes MC, Barros, AS, Silva LMS, Nóbrega MFB, Silva MRF, Torres RAM. Análise da atuação do enfermeiro na gerência de Unidades Básicas de Saúde. Rev Bras Enferm. 2010;63(1):11-15.

13. Musto LC, Rodney PA, Vanderheide R. Toward interventions to address moral distress: navigating structure and agency. Nurs Ethics. 2015;22(1):91-102.

14. Chiesa AM, Veríssimo MDLOR. A Educação em saúde na prática do PSF. In: Instituto para o Desenvolvimento da Saúde; Universidade de São Paulo. Manual de enfermagem. Brasil. Brasília: Ministério da Saúde; 2001. p. 34-42.

15. Afonso MLM. Oficinas em Dinâmica de Grupo: um método de intervenção psicossocial. São Paulo: Casa do Psicólogo; 2006.

16. Brotto FO. Jogos cooperativos: o jogo e o esporte como um exercício de convivência. $4^{\mathrm{a}}$ ed. São Paulo: Palas Athena; 2013.

17. Laabs CA. Primary care nurse practitioners' integrity when faced with moral conflict. Nurs Ethics. 2007;14(6):795-809.

18. Veer AJE, Francke AL, Struijs A, Willems DL. Determinants of moral distress in daily nursing practice: A cross sectional correlational questionnaire survey. Int J Nurs Stud. 2013;50(1):100-8.

19. Carnevale FA. Confronting moral distress in nursing: recognizing nurses as moral agents. Rev Bras Enferm. 2013;66(n.spe):33-8.

20. Schmidt DRC, Palandini M, Biato C, Pais JD, Oliveira AR. Qualidade de vida no trabalho e Burnout em trabalhadores de enfermagem de Unidade de Terapia Intensiva. Rev Bras Enferm. 2013;66(1):13-7.

21. Albuquerque FJB, Melo CF, Araújo Neto JL. Avaliação da Síndrome de Burnout em profissionais da estratégia da saúde da família da capital paraibana. Psicol Reflex Crít. 2011;25(3):542-9.

22. Silva ATC, Menezes PR. Burnout syndrome and common mental disorders among community-based health agents. Rev Saúde Pública. 2008;42(5):921-9.

23. Mendes AM, Morrone CF. Vivências de prazer, sofrimento e saúde psíquica no trabalho: trajetória conceitual e empírica. In: Mendes AM, Borges LO, Ferreira MC organizadores. Trabalho em transição, saúde em risco. Brasília: Ed. UnB; 2002. p. 25-42.

24. Fernandes HN, Thofehm MB, Porto AR, Amestoy SC, Jacondino MB, et al. Relacionamento interpessoal no trabalho da equipe multiprofissional de uma unidade de saúde da família. Rev Pesqui Cuid Fundam Online. 2015;7(1):1915-26.

25. Melo MB, Barbosa MA, Souza PR. Job satisfaction of nursing staff: integrative review. Rev Latino Am Enfermagem. 2011;19(4):1047-55.

26. Francischini AN, Moura SDRP, Chinellato M. A importância do trabalho em equipe no Programa de Saúde da Família. Rev Investig. 2008;8(1-3):25-32.

27. Rosemberg MB. Comunicação não violenta: técnicas para aprimorar relacionamentos pessoais e profissionais. $4^{\mathrm{a}}$ ed. São Paulo: Ágora; 2006.

28. Demarzo MMP, Garcia-Campayo J. Manual prático Mindfulness: curiosidade e aceitação. São Paulo: Palas Athena; 2015.

29. Demarzo MMP, Andreoni S, Sanches N, Perez S, Fortes S, Garcia-Campayo J. Mindfulness-based stress reduction (MBSR) in perceived stress and quality of life: an open, uncontrolled study in a Brazilian healthy sample. Explore (NY). 2014;10(2):118-20.

30. Copanitsanou P, Fotos N, Brokalaki H. Effects of work environment on patient and nurse outcomes. Br J Nurs. 2017;26(3):172-76.

31. Brasil. Ministério da Saúde. Plano Nacional de Saúde - PNS 2012-2015. Brasília: Subsecretaria de Planejamento e Orçamento; 2011.

32. Silva ATC, Menezes PR. Burnout syndrome and common mental disorders among community-based health agentes. Rev Saúde Pública. 2008;42(5):921-9.

33. Steinberg BA, Klatt M, Duchemin AM. Feasibility of a Mindfulness-based intervention for surgical intensive care unit personnel. Am J Crit Care. 2016;26(1):10-18.

34. Krasner MS, Epstein RM, Beckman H, Suchman AL, Chapman B, Mooney CJ, et al. Association of an educational program in mindful communication with burnout, empathy, and attitudes among primary care physicians. JAMA. 2009;302(12):1284-93.

35. Felli VEA. Condições de trabalho de enfermagem e adoecimento: motivos para a redução da jornada de trabalho para 30 horas. Enferm Foco. 2012;3(4):178-81

36. Dyo M, Kalowes P, Devries J. Moral distress and intention to leave: a comparison of adult and paediatric nurses by hospital setting. Intensive Crit Care Nurs. 2016;36(1):42-8.

37. Borhani F, Abbaszadeh A, Nakhaee N, Roshanzadeh M. The relationship between moral distress, professional stress, and intent to stay in the nursing profession. J Med Ethics Hist Med. 2014;7:3eCollection.

38. Trautmann J, Epstein E, Rovnyak V, Snyder A. Relationships among moral distress, level of practice independence, and intent to leave of nurse practitioners in emergency departments: results from a national survey. Adv Emerg Nurs J. 2015;37(2):134-45.

39. Prestia AS, Sherman RO, Demezier C. Chief nursing officers experiences with moral distress. J Nurs Adm. 2017;47(2):101-7.

Financial support:

Coordenação de Aperfeiçoamento de Pessoal de Nível Superior (CAPES). Process number BEX 1050/13-3. 